\title{
Reconstructions of the continents around the North Atlantic at about the 60th parallel
}

\author{
Trond H. Torsvik ${ }^{\mathrm{a}, \mathrm{d}}$, Rob Van der Voo ${ }^{\mathrm{b}, *}$, Joseph G. Meert ${ }^{\mathrm{a}, \mathrm{e}}$, Jon Mosar ${ }^{\mathrm{a}}$, \\ Harald J. Walderhaug ${ }^{\mathrm{c}}$ \\ a VISTA, clo Geological Survey of Norway, Leiv Eiriksonsvei 39, N-7491 Trondheim, Norway \\ b Department of Geological Sciences, University of Michigan, Ann Arbor, MI 48109-1063, USA \\ c University of Bergen, Institute of Solid Earth Physics, Allegt. 41, N-5007 Bergen, Norway \\ d Institute for Petroleum Technology and Applied Geophysics, S.P. Andersens v. 15a, N-7491 Trondheim, NTNU, Norway \\ e Department of Geography and Geology, Indiana State University, Terre Haute, IN 47809, USA
}

Received 12 September 2000; received in revised form 16 February 2001; accepted 21 February 2001

\begin{abstract}
Late Carboniferous-Early Tertiary apparent polar wander (APW) paths (300-40 Ma) for North America and Europe have been tested in various reconstructions. These paths demonstrate that the 500 fathom Bullard et al. fit is excellent from Late Carboniferous to Late Triassic times, but the continental configuration in northern Pangea changed systematically between the Late Triassic (ca. $214 \mathrm{Ma}$ ) and the Mid-Jurassic (ca. $170 \mathrm{Ma}$ ) due to pre-drift extension. Best fit North Atlantic reconstructions minimize differences in the Late Carboniferous-Early Jurassic and Late CretaceousTertiary segments of the APW paths, but an enigmatic difference exists in the paths for most of the Jurassic, whereas for the Early Cretaceous the data from Europe are nearly non-existent. Greenland's position is problematic in a Bullard et al. fit, because of a Late Triassic-Early Jurassic regime of compression $(>300 \mathrm{~km})$ that would be inherently required for the Norwegian Shelf and the Barents Sea, but which is geologically not defensible. We suggest a radically new fit for Greenland in between Europe and North America in the Early Mesozoic. This fit keeps Greenland 'locked' to Europe for the Late Paleozoic-Early Mesozoic and maintains a reconstruction that better complies with the offshore geological history of the Norwegian Shelf and the Barents Sea. Pre-drift (A24) extension amounted to approximately $450 \mathrm{~km}$ on the Mid-Norwegian Shelf but with peak extension in the Late Cretaceous.
\end{abstract}

Keywords: North Atlantic; apparent polar wandering; reconstruction; paleogeography; extension

\section{Introduction}

Magnetic anomaly fits have been used extensively for North Atlantic reconstructions, begin-

\footnotetext{
* Corresponding author. Tel.: +1-734-764-8322; Fax: +1-734-763-4690; E-mail: voo@umich.edu
}

ning with anomaly A33 (73.619-79.075 Ma) or A24 (52.364-53.347 Ma) which are the oldest chrons identified in the Labrador Sea and the North Atlantic, respectively [1-3]. It is well known that reconstructions for older times differ from those based on the oldest magnetic anomalies, because the latter do not account for pre-drift extension. Late Paleozoic to Early Mesozoic paleopoles from Europe and North America thus do 
not superimpose when using magnetic anomaly fits or 'backward' extrapolated fits (stage-poles) even though these may attempt to account for some intra-plate deformation due to pre-drift extension (e.g. [4]). However, we argue that the relative position of continents for pre-drift periods can be well determined when sufficiently reliable paleomagnetic data are available [5-7]. The net difference between such a paleomagnetic fit and a fit commencing with the first magnetic anomaly would approximate pre-drift extension. As we will show in this study, this works well for the North Atlantic, even though for the Late Jurassic and Early Cretaceous the paleomagnetic data either are too scarce or have questionable reliability.

The majority of Pangea reconstructions are essentially for the Late Triassic/Early Jurassic and assume insignificant post-Permian intra-plate deformation. However, Lottes and Rowley [4] did incorporate some syn- to post-Late Triassic intra-plate deformation along with the sea-floor spreading history into their reconstructions, but domains of Mesozoic extension around the North Atlantic, including the North Sea, the basins offshore Norway and Greenland, and the Barents Shelf were not included. The amount of pre-Cretaceous extension in the Rockall area, northwest of the UK and the Irish continental margins, is also debated [8].

Several pre-drift reconstructions of the North Atlantic exist in the literature and one of these [9] is based on least-square fitting of 500 fathom (ca. $900 \mathrm{~m}$ ) contours across the North Atlantic. Van der Voo [6,7] has shown that this reconstruction is superior to all others in matching North American and European paleopoles from Mid-Paleozoic to Jurassic times. For this reason, many Mid-Paleozoic to Early Mesozoic reconstructions employ the Bullard et al. [9] reconstruction for Laurentia (North America, Greenland and Scotland) and Baltica/Stable Europe (e.g. [10,11]). While this reconstruction may also be the best approximation of the initial opening configuration of the North Atlantic (e.g. [12]), a fundamental problem remains: did any early extension occur in this pre-drift reconstruction [9] and when did it change to the fit based on the oldest anomalies? In order to shed some light on these issues we have undertaken a comprehensive up to date compilation and analysis of Late Paleozoic-Cenozoic paleomagnetic data from the North Atlantic bordering continents (Fig. 1). We have generated new apparent polar wander (APW) paths, developed best fit North Atlantic reconstructions, and discussed their implications for paleogeography and pre-drift extension.

\section{Late Paleozoic-Cenozoic paleomagnetic data}

\subsection{Paleopoles}

Reliable paleomagnetic poles $(Q \geq 3$ [7]) from North America (including Ellesmere), Greenland, and Europe (including Svalbard) have been compiled and evaluated. Excluding far northern ('Arctic') areas for reasons explained below, the compilation includes 130 poles from North America (40-300 Ma) and 94 poles from Europe (50-300 $\mathrm{Ma})$. 'Arctic' poles comprise 14 poles from Greenland (54-230 Ma), seven poles from Svalbard (110-272 Ma) and four poles from Ellesmere Island (62-274 Ma). Our age-assignments accord with the stratigraphic time-scales of Gradstein et al. [13] and Berggren et al. [14]. All selected paleomagnetic poles are listed in table $1(\mathrm{a}-\mathrm{e})$ in the EPSL Online Background Dataset ${ }^{1}$.

The bulk of North American poles (Fig. 2A) come from eastern and western North America (Fig. 1). Poles from the Colorado Plateau have been corrected for a Laramide counter-clockwise rotation of about $5.4^{\circ}$ [15]. Larger rotation angles have also been proposed (see review in [16]), but we use the smaller angle to stay on the conservative side.

The European poles (Fig. 2B) are mostly derived from rocks from Central Europe, Scandinavia and the British Isles (Fig. 1). The bulk of the results are of Late Carboniferous-Early Triassic and Early Tertiary age. Unfortunately, Jurassic and Cretaceous poles, critical to our analysis (see below), are scarce. This is mostly due to the 


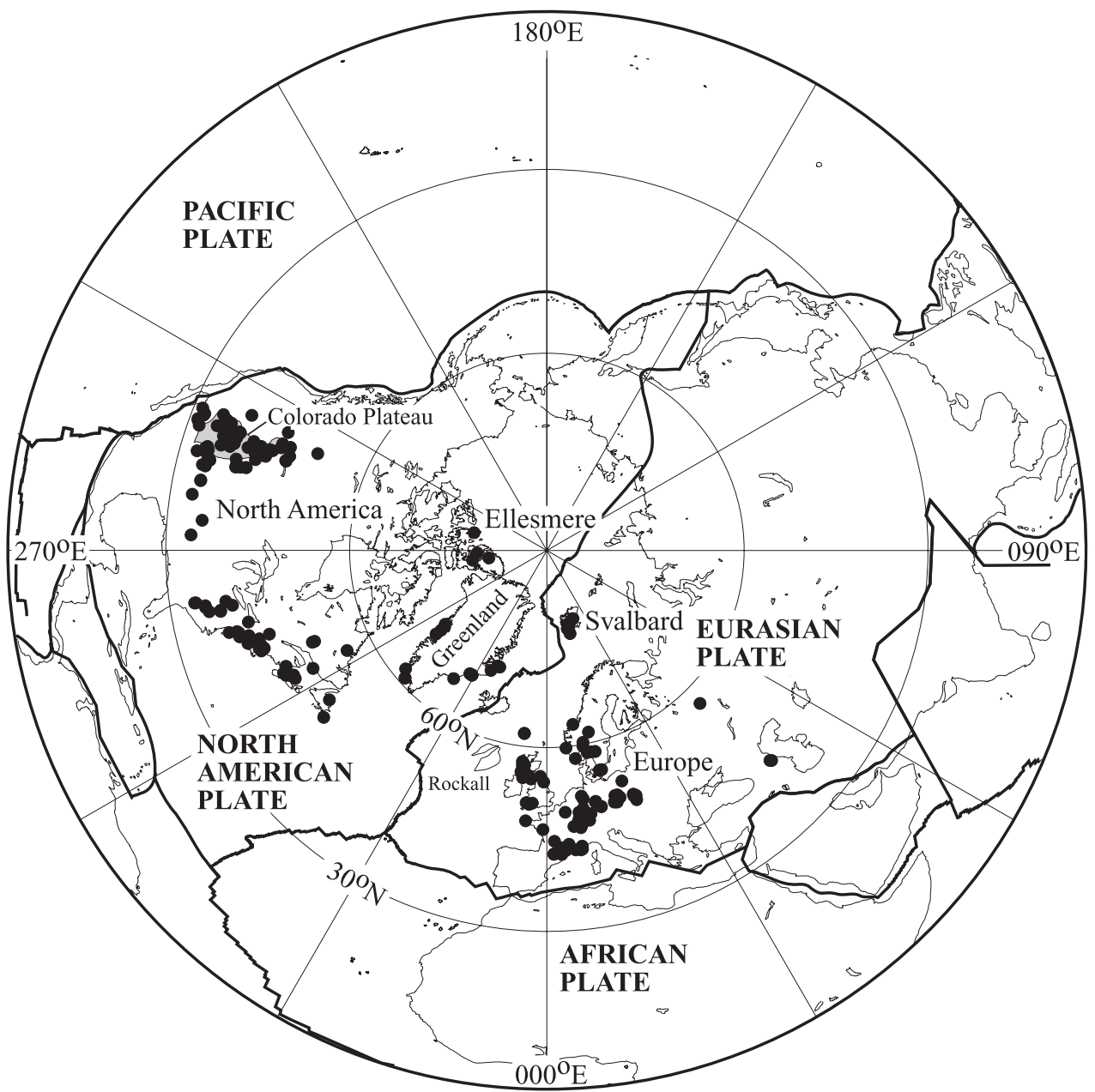

Fig. 1. Map of the North Atlantic showing locations for paleomagnetic studies analyzed in this paper (table 1 in the EPSL Online Background Dataset ${ }^{1}$ ). Present plate boundaries and regional extent of the Colorado Plateau are shown. Equal area polar projection.

lack of suitable rocks of these ages; Jurassic and younger sediments are often unconsolidated (e.g. in Sweden, Denmark and UK). In addition, while suitable Jurassic and Cretaceous formations in southern Europe yield good paleomagnetic results, the prevalence of Alpine deformation and microplate movements rendered the poles unsatisfactory for the present analysis.

There are few paleomagnetic poles from Greenland, and they are mainly of Mid-Late Triassic (three internally clustered poles from SE Greenland) or Early Tertiary age (Fig. 2C). The Trap (coast-parallel) Dikes in SW Greenland have re- cently been dated between 133 and $138 \mathrm{Ma}$ [17]; we have combined three paleomagnetic studies from these dikes and assigned a mean age of $135 \mathrm{Ma}$ (Fig. 2C; see table 1c in the EPSL Online Background Dataset ${ }^{1}$ ). Reliable Early Tertiary paleomagnetic data come from the North Atlantic Igneous Province (NAIP), which includes the UK, Ireland, and the Faeroes as well as Greenland [18]. Upon reconstruction, paleopoles from the NAIP are reasonably grouped, but paleopoles from Greenland are anomalous as discussed below.

Paleomagnetic poles from Svalbard are few 
(Fig. 2D), and of variable quality. Permian and Early Triassic poles are scattered (four poles) whereas poles from Late Jurassic-Cretaceous dolerite dikes show a NE-trending polar wander track that only approximately resembles that of Europe. The age of these dikes is not firmly established (being based on K/Ar whole rock ages), with exception of the Hinlopen dolerites, dated

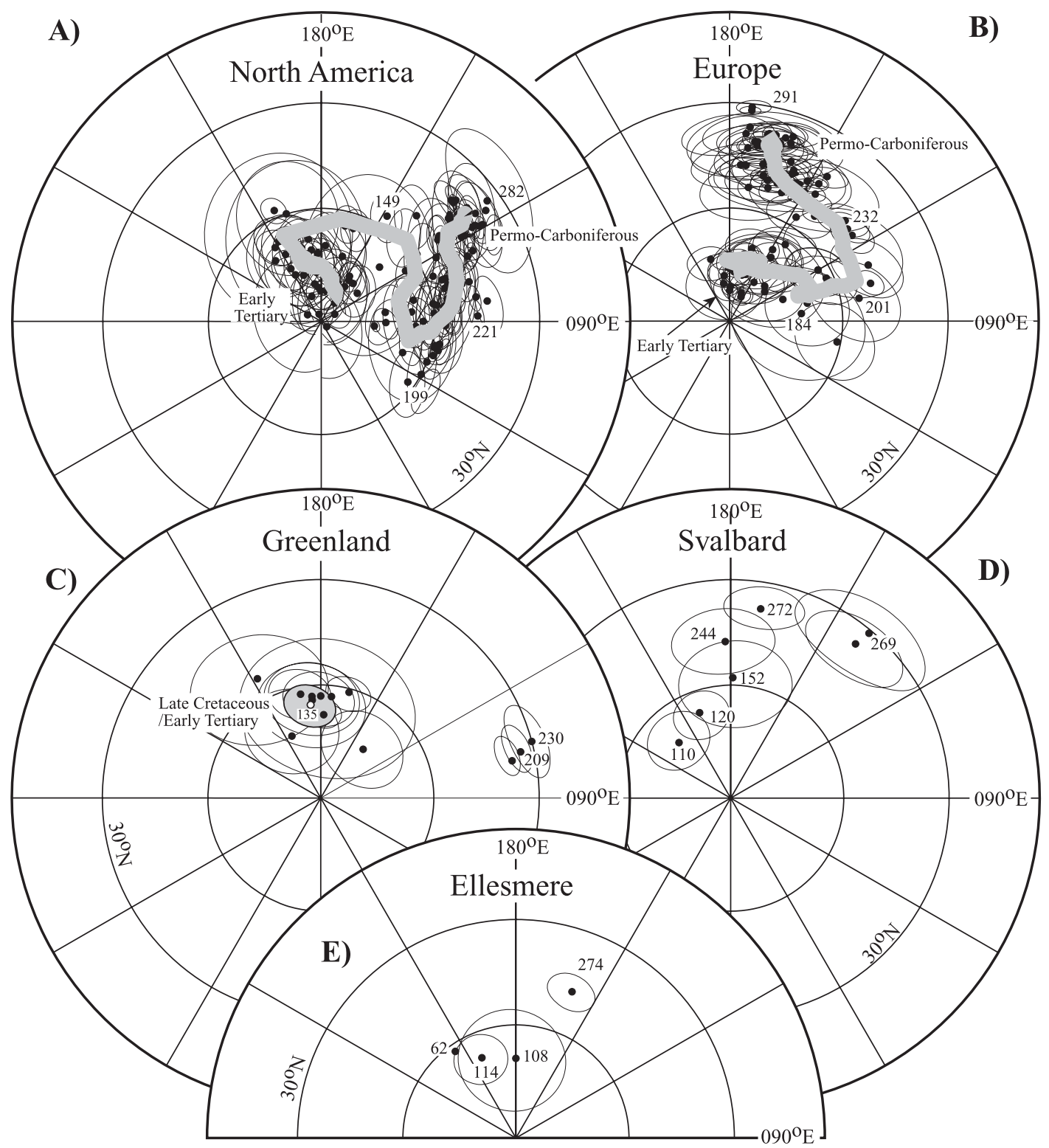

Fig. 2. Individual Late Carboniferous to Early Tertiary paleomagnetic poles from (A) North America, (B) Europe, (C) Greenland, (D) Svalbard and (E) Ellesmere. All poles are shown with dp/dm semi-axes except a few poles from North America shown with $a_{95}$ confidence circles. RM apparent polar (APW) paths are overlain on the poles in (A) and (B). In (A) and (B) we have only denoted a few ages for diagram clarity (all numbers are in million years). In (C) we have highlighted a 135 Ma pole from Greenland; this pole combines site-mean data from three individual studies of coast-parallel dikes in SW Greenland, which recently have been dated as between 133 and 138 Ma. See table 1 in the EPSL Online Background Dataset ${ }^{1}$ for details. Equal area polar projection. 
as $120 \mathrm{Ma}(\mathrm{U} / \mathrm{Pb}(\mathrm{S}$. Dahlgren, personal communication)).

Four poles are included from Ellesmere Island; one Permian and three Cretaceous results (Fig. 2E). The authors of the study [19] describing the Permian result argue that its locality is rotated, but its paleolatitude should not be significantly affected by the rotation. The paleopole location is indeed very different from the coeval North American poles.

\subsection{North American and European APW paths}

Using the available paleomagnetic poles (table 1 in the EPSL Online Background Dataset ${ }^{1}$ ) we experimented with different methods of generating APW paths, using running means (RM) as well as spherical spline methods $[11,20]$. Of these two methods, RM is the simplest; we have used a 20 Myr moving window. Table 2 in the EPSL Online Background Dataset ${ }^{1}$ lists the means, using $5 \mathrm{Myr}$ increments. Figs. 2 and $3 \mathrm{~A}$ illustrate the two individual paths for the European and North American continents. The results from the Arctic areas (Ellesmere, Greenland and Svalbard) are excluded, because as Fig. 2 shows, and as discussed in detail below, the results from these northern areas systematically disagree with those from the main parts of the two continents. The European and North American paths at first glance have roughly congruent shapes, as also observed in earlier studies (e.g. [6]); they will be fitted together and combined after a discussion in Section 3 of the reconstruction parameters.

In the RM method, the poles are not weighted, e.g. according to angular uncertainty $\left(a_{95}\right)$. The spherical spline method is more advanced and flexible as poles can be weighted by either $a_{95}$ or according to their performance in the Van der Voo [7] reliability classification scheme. The spline path is therefore firmly anchored to the most reliable data and only loosely guided by the remainder [10]. We observe only minor differences using RM or the more complex spline method (Fig. 3C) for the combined North America-Europe APW path (table 2 in the EPSL Online Background Dataset $^{1}$; listed as both RM and spline paths). On the other hand, a RM path is advantageous when undertaking non-dipole field analysis since a sampling site center of gravity for a mean pole can be easily computed [21].

\section{North Atlantic reconstruction parameters}

\subsection{North America vs. Europe}

In order to test different fits for North America and Europe, we calculate the great circle distance (GCD, in degrees) between mean poles (table 2 in the EPSL Online Background Dataset ${ }^{1}$ ) of similar age ( $<5$ Ma difference). In Fig. 4A, four different fits are evaluated: the Bullard et al. [9] fit, a 170 Ma stage-pole reconstruction [22], a magnetic anomaly fit (A24, ca. $53.4 \mathrm{Ma}$ ), and a best fit developed in this study. Fig. 4A clearly shows that the Bullard et al. fit [9] is in excellent agreement with the paleopoles from the two main North Atlantic bordering continents for the interval 300-214 Ma. This fit yields GCDs mostly below $5^{\circ}$ (Fig. 4A), and the cones of confidence of the mean European and North American poles overlap. For times younger than $214 \mathrm{Ma}$, the GCDs gradually increase in the Bullard et al. [9] reconstruction, showing offsets above $20^{\circ}$ in Cretaceous times. We conclude that the Bullard et al. [9] reconstruction is applicable from Silurian $[7,11]$ to the Late Triassic, but not for later times.

In contrast, the ca. $170 \mathrm{Ma}$ rotation pole of Royer et al. [22] improves the Late Jurassic and, especially, the Cretaceous sections, but produces a large misfit for the Permo-Carboniferous (Fig. $4 \mathrm{~A})$, rendering this reconstruction untenable for earlier times. A magnetic anomaly (A24) fit of Roest et al. (personal communication) for the North Atlantic (Eurasia vs. North America) produces a good fit in Late Cretaceous-Early Tertiary times, but has little relevance for the Late Paleozoic-Early Mesozoic section (the GCD misfit for Late Carboniferous-Permian times can be as large as $28^{\circ}$; Fig. $4 \mathrm{~A}$ ).

We observe, therefore, from experimenting with various magnetic anomaly reconstructions, stage or initial opening fits, that no single fit accommodates the entire extent of the 300-40 Ma APW paths for North America and Europe. To some 

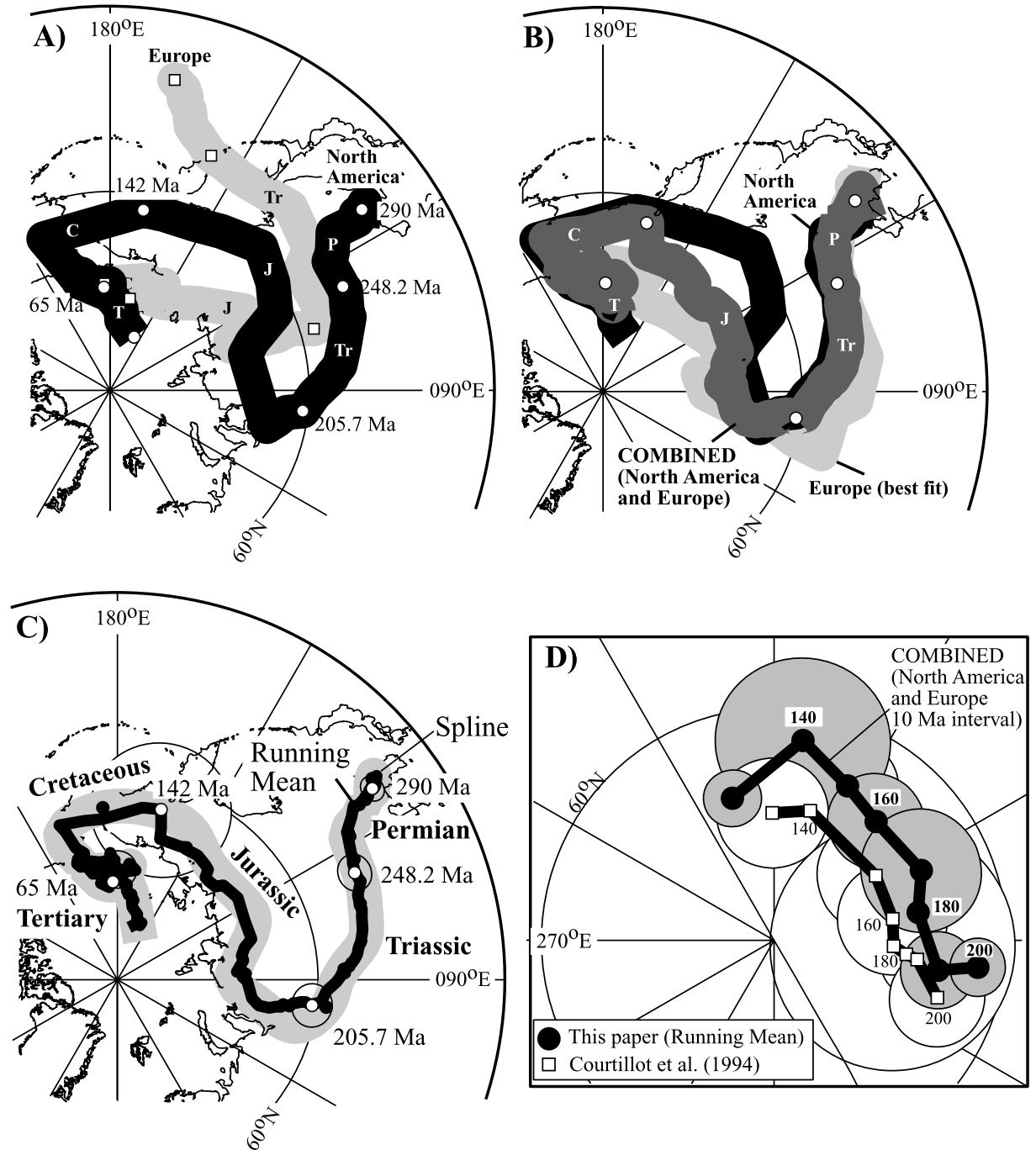

Fig. 3. (A) Comparison of North American and European APW paths (RM paths from Fig. 2). (B) European RM path fitted to the North American path and a combined RM path based on all individual poles after appropriate rotations. (C) Comparison of the combined RM path (with selected $a_{95}$ confidence circles) and an APW path constructed with the spherical spline method (smoothing parameter $=200$; poles weighted according to their performance in the Van der Voo [7] $Q$-factor; see [11] for method). These paths are very similar and overlap statistically, except for the poles near the Jurassic-Cretaceous boundary. (D) Comparison of our combined North America-Europe Jurassic-Early Cretaceous RM path with a synthetic North American RM path of Courtillot et al. [24]. Numbers denote millions of years. Except (D) our European and North American paths use 20 Myr moving windows and $5 \mathrm{Myr}$ increments. The combined RM path uses $1 \mathrm{Myr}$ increments. Paths are listed in table 2 in the EPSL Online Background Dataset ${ }^{1}$.

extent this is due to the profound difference in, and the poor quality of, the Late Jurassic APW segments (Fig. 3B; high-latitude European poles vs. intermediate-latitude North America poles; see discussion in [7]). Moreover, the scarcity of Late Mesozoic results from Europe or even their complete absence (Early Cretaceous, 125-100 Ma) prevents definite comparisons (Fig. 4B).

We thus face a situation where the Late Paleozoic-Early Mesozoic paleopoles are well matched by the Bullard et al. [9] fit, while Late CretaceousEarly Tertiary poles are matched well with mag- 
netic anomaly fits. The intervening Mid-Jurassic to Early Cretaceous segment is problematic (unless one invokes radically different fits that kinematically involve to-and-from movements between Europe and North America). Cretaceous and Jurassic stage-poles for the North Atlantic have been published by several authors and we have used Late Jurassic-Early Cretaceous (145$118 \mathrm{Ma}$ ) stage-poles by Srivastava and Roest [2], the Mid-Jurassic stage-pole (ca. $170 \mathrm{Ma}$ ) by Royer et al. [22] and Late Cretaceous stage-poles of Roest et al. (personal communication).
In summary, our optimized fit for Europe vs. North America (table 3 in the EPSL Online Background Dataset ${ }^{1}$; Fig. 3, combined path) employs (1) the Bullard et al. [9] fit from Late Carboniferous to Late Triassic (300-214 Ma) times, (2) a gradually changing reconstruction with Euler poles that are being constantly interpolated from 214 to $55 \mathrm{Ma}$, including a previously published fit for $170 \mathrm{Ma}$ [22], and (3) magnetic anomaly fits for the Tertiary $(<54 \mathrm{Ma})$. Our analysis differs from that of Srivastava and Verhoef [12] in that we do not use a Bullard et al. [9] fit for the Jurassic, but

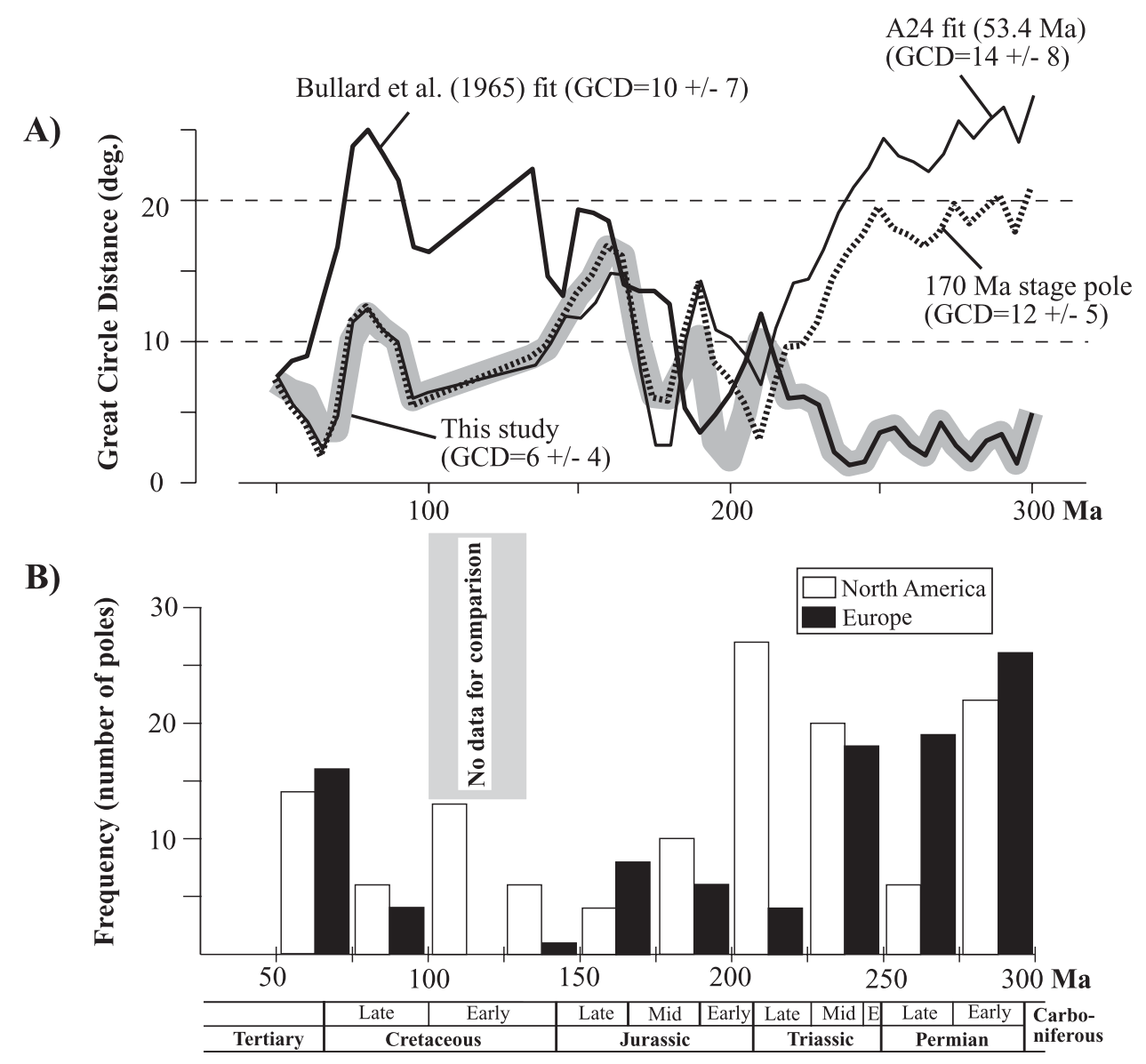

Fig. 4. (A) Calculated GCD between coeval points on the North American and European APW paths (RM type) using (1) a Bullard et al. [9] fit (Euler pole: Lat. $=88^{\circ} \mathrm{N}$, Long. $=27^{\circ} \mathrm{E}$, rotation angle $=-38^{\circ}$ ), (2) $170 \mathrm{Ma}$ stage-pole fit of Royer et al. [22] (Euler pole: Lat. $=69.1^{\circ} \mathrm{N}$, Long. $=156.7^{\circ} \mathrm{E}$, rotation angle $\left.=-23.64^{\circ}\right)$, (3) A24 fit of Roest et al. (personal communication) $($ Euler pole: Lat. $=62.62^{\circ} \mathrm{N}$, Long. $=143.43^{\circ} \mathrm{E}$, rotation angle $=-12.821^{\circ}$ ), and (4) our optimized transitional fit (shaded swathe in figure; table 3 in the EPSL Online Background Dataset ${ }^{1}$; see text). All fits are shown for Late Paleozoic-Early Tertiary times, and GCDs (degrees $\pm s$ ) are mean values calculated over this time interval. GCDs are calculated from RM paths in Fig. 3A. (B) Frequency histogram by age of individual poles from North America and Europe (50-300 Ma). 
instead employ an interpolation from Late Triassic (214 Ma) to Mid-Jurassic times (when the ca. $170 \mathrm{Ma}$ stage-pole of [22] applies) in order to produce the best match between the APW paths.

\subsection{A combined North America-Europe APW path}

Our optimized (combined) fit yields an average GCD of $6 \pm 4^{\circ}$ (Fig. 4) between the reconstructed European and North American paleopoles. Based on the rotation parameters of table 3 in the EPSL Online Background Dataset ${ }^{1}$ we rotated European paleopoles into a North American frame and then calculated a combined North America-Europe APW, using both the RM (unit weight) and spline (weighted according to $Q$-factor) methods (Fig.
3C). Since the European dataset is lacking Cretaceous results, the combined path closely follows the North American path for this time period. We stress again that the bulk of Jurassic poles from North America and Europe differ and produce parallel but offset APW paths with a large misfit. Several synthetic North America paths exist in the literature (see [7]). They differ due to data selection and reconstruction fits. For example, we have compared a segment (Jurassic-Early Cretaceous) of our combined North America-Europe RM path with a synthetic North America RM path (Fig. 3D) based on poles from South America, South Africa, West Africa and Eurasia [24]. The latter path is systematically offset from ours and more closely resembles our European path (in North American co-ordinates).
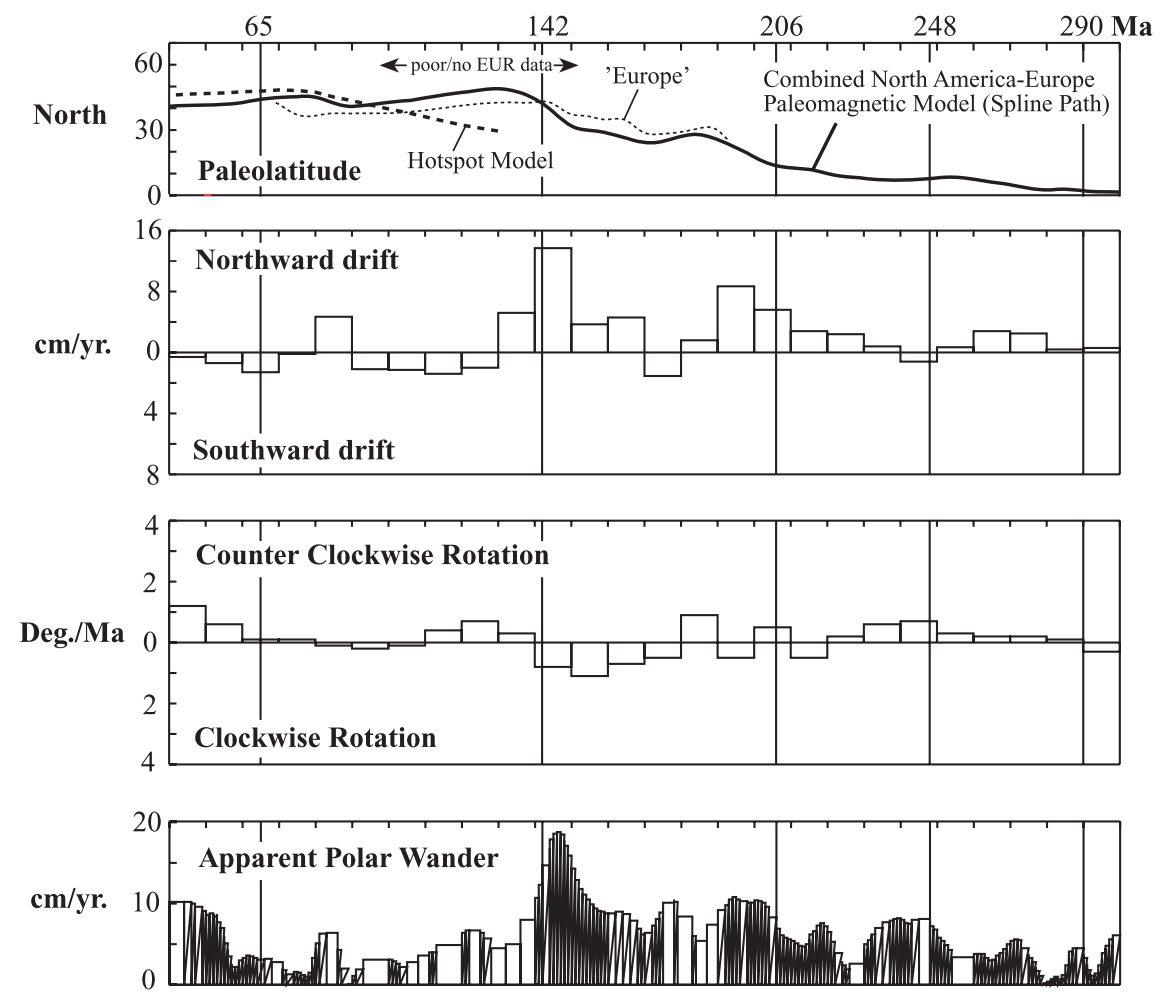

Fig. 5. Paleolatitude, latitudinal drift rate and rate of angular rotation for a location in Central North America $\left(45^{\circ} \mathrm{N} / 270^{\circ} \mathrm{E}\right)$. Bottom figure is rate of APW (independent of location). All calculations are based on a combined spherical spline path for North America-Europe (table 2 in the EPSL Online Background Dataset ${ }^{1}$ ). Stippled line in top diagram is the calculated latitudinal curve (40-130 Ma) for the same North American location using the hotspot model of Müller et al. [23]. Note the large offset in the Early Cretaceous; Early Cretaceous latitudes based on paleomagnetic data in the combined path are strongly dependent on the North American dataset (see text), and for comparison we show latitudes predicted for the same North America location based on our European data only (illustrated for Jurassic and Cretaceous times). 
Fig. 5 shows paleolatitudinal change, latitudinal drift rate and rate of angular rotation for a location in central North America $\left(45^{\circ} \mathrm{N}, 270^{\circ} \mathrm{E}\right)$, based on a combined spline path for North America-Europe (table 2 in the EPSL Online Background Dataset ${ }^{1}$ ); analytical procedures follow Torsvik et al. [10,11]. The rate of APW (bottom of Fig. 5) is independent of location. North America (i.e. present-day $45^{\circ} \mathrm{N}$ ) was situated at equatorial and sub-tropical latitudes during Late $\mathrm{Pa}$ leozoic and Early Mesozoic times but with a pronounced northerly track until the Early Cretaceous. Latitudinal velocities are typically below $5 \mathrm{~cm} / \mathrm{yr}$, but with a velocity burst in Late Jurassic-Early Cretaceous times (ca. $14 \mathrm{~cm} / \mathrm{yr}$ ). Rotations of the continent have been small and typically below $1 \% \mathrm{Ma}$. APW rates, the combined effects of continental drift and true polar wander (TPW) (if any), have been typically below $10 \mathrm{~cm} /$ yr, except in the Late Jurassic when a peak value of nearly $20 \mathrm{~cm} / \mathrm{yr}$ was reached (Fig. 5).

Paleomagnetically derived latitudes compare a)

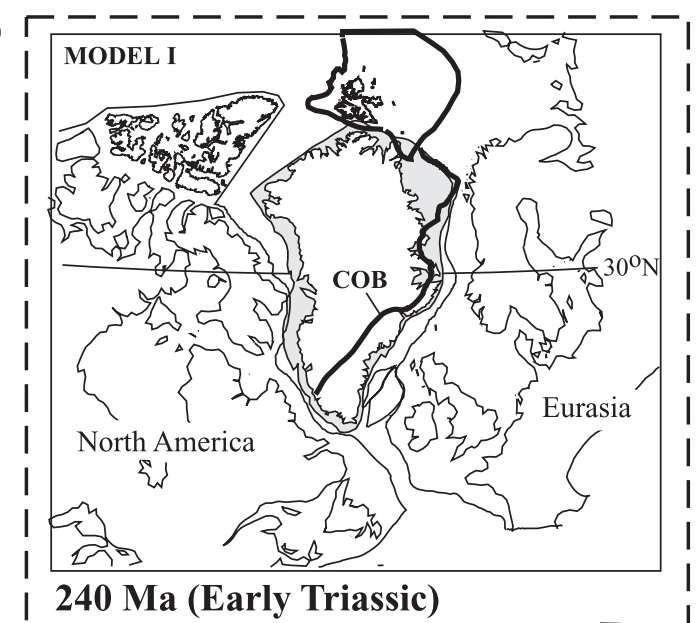

b)

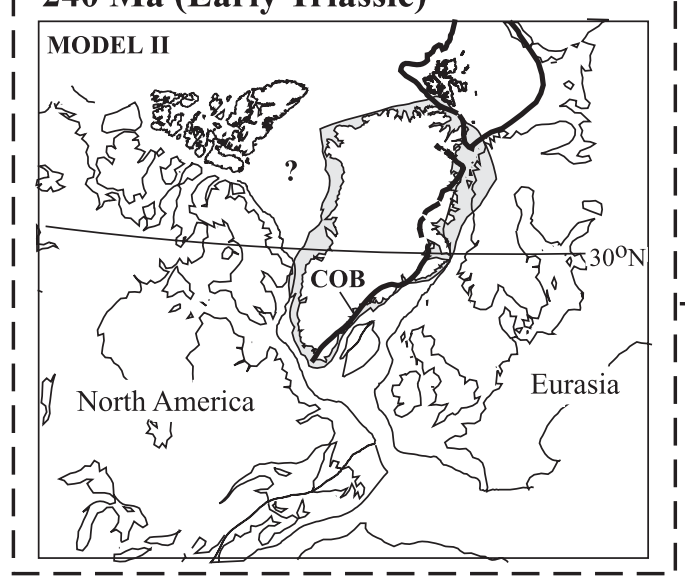

d)

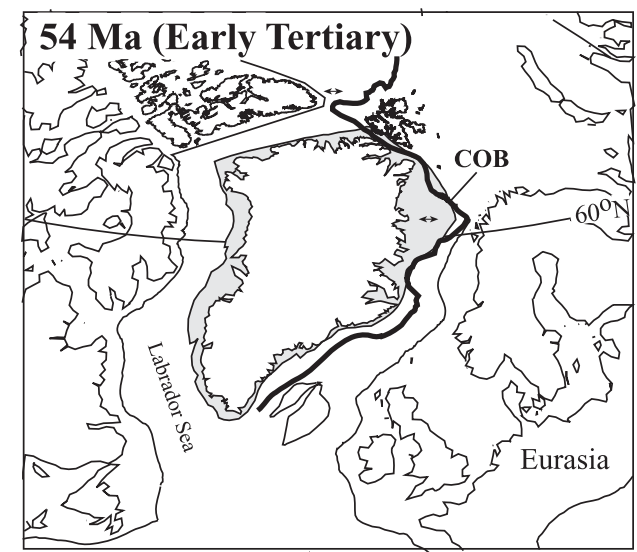

c)
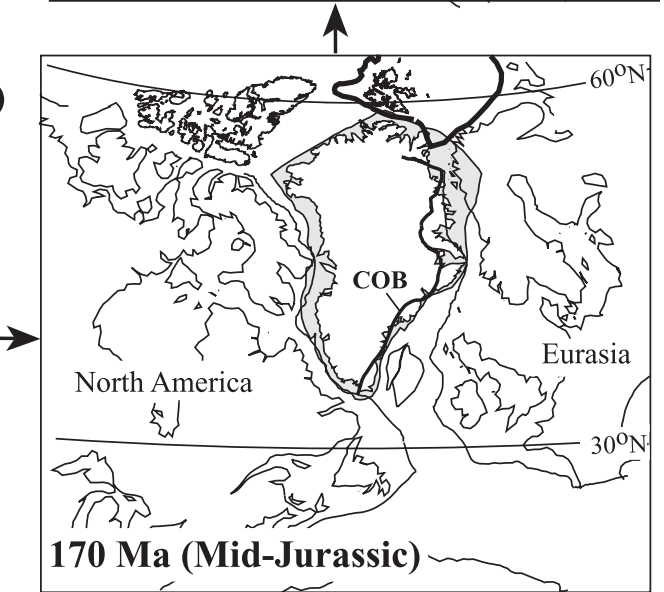

Fig. 6. Early Triassic (a, b), Mid-Jurassic (c) and Early Tertiary (d) paleogeographic reconstructions using the paleolatitudes from the combined RM North America-Europe path. $\mathrm{COB}=$ continent-ocean boundary for the Eurasian Plate. Two models are shown for the Early Triassic. Model I maintains a classic Bullard et al. [9] fit between North America-Greenland-Eurasia. Model II maintains a Greenland-Eurasia fit as for the Mid-Jurassic in order to avoid large compression in the Mid-Norwegian and Barents Sea shelf during Late Triassic-Early Jurassic times; this compression would be a consequence of Model I, but is geologically unacceptable. Conversely, Model II requires significant post-Early Triassic compression, and/or major right-lateral strikeslip displacements between North America and Greenland. There is evidence for major Early Triassic to Cretaceous right-lateral deformation and pull-apart basin development in the northwestern Greenland/Ellesmere Island region [37,38], but the consequences of Model II need further study. Relative fits are listed in table 3 in the EPSL Online Background Dataset ${ }^{1}$. 
reasonably well (within $5^{\circ}$ ) with those calculated from the hotspot frame [23], except for the Early Cretaceous (Fig. 5); the latter has been ascribed to TPW or hotspot migration in the Early Cretaceous [18].

\subsection{Greenland}

During Precambrian and Paleozoic times, Greenland is considered a part of Laurentia (North America plus Greenland and northern Scotland). Greenland separated from North America during the Late Cretaceous (A33), but sea-floor spreading ceased in the Labrador Sea after A21 (modeled to have ceased at ca. $35 \mathrm{Ma}$ in table 3 in the EPSL Online Background Dataset $^{1}$ ), so that Greenland is presently again part of the North American plate. Initial and magnetic anomaly fits have been published by Roest and Srivastava [1], or can be calculated from a Bullard et al. [9] fit.

Mesozoic poles from Greenland are few and problematic, and cannot be used to test any of the reconstructions. Within the framework and constraints of our Eurasia-North America fits we have estimated Greenland-North America fits using two different models (I and II, Fig. 6a,b). Both models conform with magnetic anomaly fits in the NE Atlantic and the Labrador Sea for Late Cretaceous and Tertiary times, but the earlier Mesozoic fits differ substantially.

Model I juxtaposes Greenland and North America in a tight Bullard et al. [9] fit (recalculated) during the Early Mesozoic. This is a 'classic' Greenland-North America reconstruction, but it produces a loose fit for the NorwegianGreenland Sea and a tight fit in the Rockall Bank area (Fig. 6a). Model II is similar to Model I for Cretaceous-Tertiary times (Fig. 6d), but it keeps Greenland 'locked' to Europe for the Late Paleozoic-Early Mesozoic. This maintains a reconstruction between Greenland and Eurasia that complies well with the offshore geological history [25], as will be described below. However, the resulting reconstruction of Model II (given the Bullard et al. fit [9] for Europe and North America) between North America and Greenland (Baffin Bay) is very puzzling and would require sev- eral hundred kilometers of post-Early Triassic compression, and/or major right-lateral strikeslip displacements.

The available paleomagnetic results appear to be of no help in resolving this issue, because irrespective of the fit used for Greenland-North America (Models I and II or any other fits), the Mid-Late Triassic poles from Greenland [26] are highly anomalous (Fig. 7A). A large local-regional clockwise rotation is suspected, but the inclinations of the three results are also anomalously low and result in a very poor latitudinal match. In a companion paper, we discuss the possibility that a significant octupole field is responsible for the discrepancy [21]. Early Cretaceous and Tertiary poles show a better, but still imperfect, correlation (Models I and II coincide in this time interval) with the combined North America-Eurasia path (Fig. 7A). Early Tertiary poles from the North Atlantic region show increased grouping when adjusted for younger sea-floor spreading, but the Greenland data are anomalous [18], and generally yield lower latitude pole positions than North America and European poles (Fig. 7A). This deviation is also best explained by a persistent octupole field.

Hartz et al. [27] showed that a Model I fit [9] produces a reasonable match between DevonianLower Carboniferous poles from Greenland and North America, and so does Model II (Fig. 7B). Because of this lack of resolution as well as the disagreement with the Triassic paleopoles (Fig. 7A), we conclude that a choice between the two models cannot be made with the available paleomagnetic data.

\subsection{Svalbard}

Svalbard was an independent microplate in the Early Paleozoic, which collided with NE Greenland, probably in Late Ordovician times [28]. Greenland and Svalbard (as part of Laurentia) subsequently collided with Baltica during the Mid-Late Silurian (ca. 425 Ma [11]). Late Paleozoic paleomagnetic data from Svalbard are of variable reliability, but given the typical resolution of paleomagnetic data, Torsvik et al. [29] and Watts [30] could argue that Svalbard was an integral 

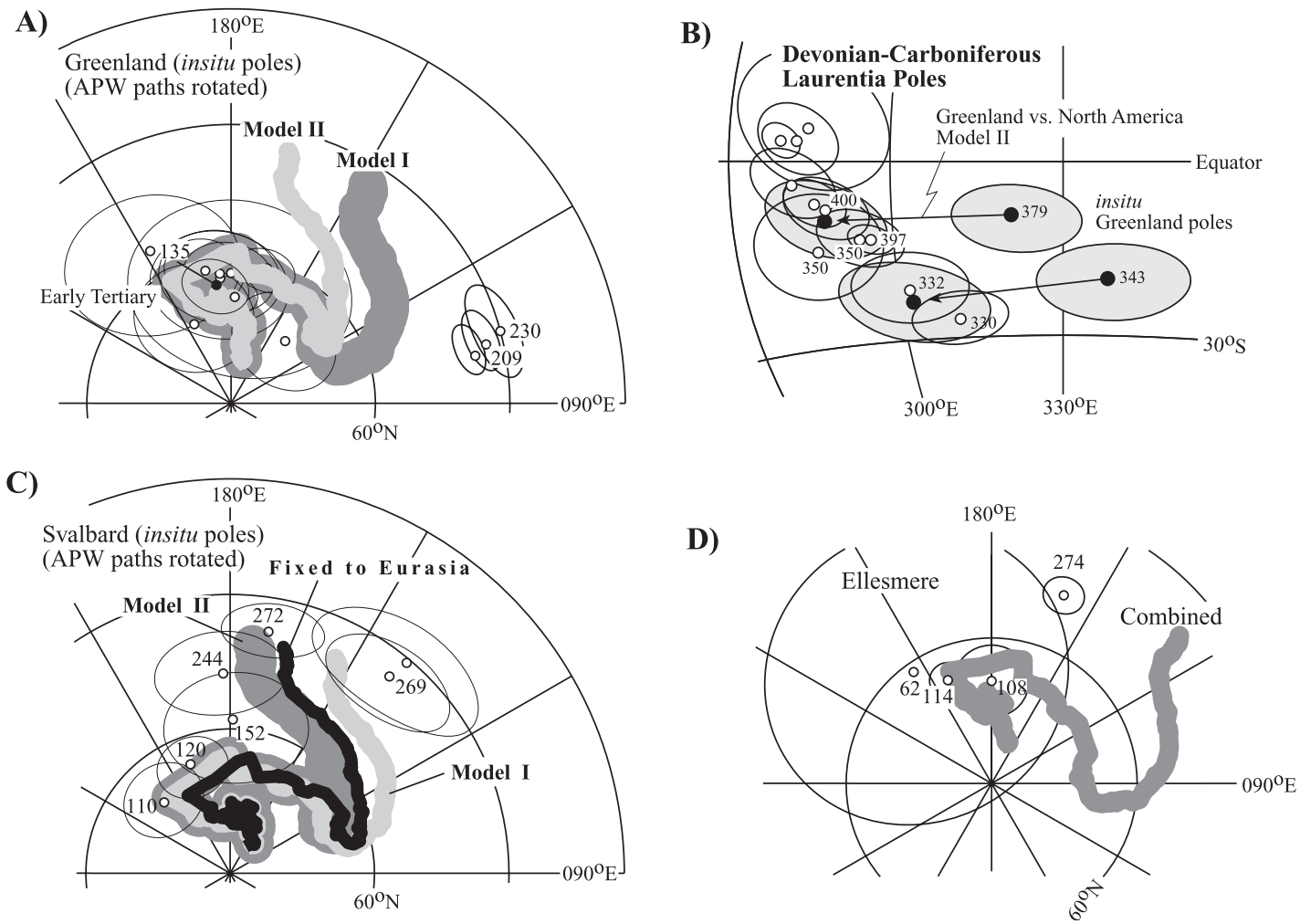

Fig. 7. (A) Greenland poles (as in Fig. 2C) compared with the combined North America-Europe RM path rotated to Greenland according to either Model I or II (Fig. 6a,b). (B) Devonian and Carboniferous poles from Laurentia (North America and Scotland poles in a Bullard et al. [9] fit; from [11]) compared with Late Devonian/Early Carboniferous poles from Greenland [27]. The two Greenland poles (379 and $343 \mathrm{Ma}$ ) are shown in Greenland and North American co-ordinates using the Model II fit (Fig. 6b). All poles are shown with ovals with dp/dm semi-axes. (C) Svalbard poles compared with the combined North America-Europe RM path rotated to Greenland according to Models I and II (Fig. 6a,b) or on the 'assumption' that Svalbard remained an integrated part of the Eurasian plate since the Permian. (D) Ellesmere poles compared with the combined North America-Europe RM path.

part of the Eurasian plate since the Devonian. Conversely, Jelenska [31] argued that Permian poles show that Svalbard did not belong to Eurasia (269 Ma poles in Fig. 7C), whereas a more recent Permian pole [32] negates this as it shows an acceptable correspondence with the Eurasian APW path (272 Ma pole in Fig. 7C). For Mesozoic times, it has been proposed that Svalbard remained contiguous with Greenland until northward progression of North Atlantic rifting and opening of the NE Atlantic in Late Cretaceous and Early Tertiary times (e.g. [33]). This implies that Svalbard and Europe were in different relative Mesozoic positions from those of today, if
Greenland is placed in the Model I reconstruction according to Bullard et al. [9] (Fig. 6a).

The 272 Ma pole [32] compares well with Eurasia, even though it falls at a somewhat lower latitude than the coeval European Early Permian reference pole (Fig. 7C). This slight deviation may again be due to the existence of non-dipole fields [21]. Comparing this Permian pole from Svalbard, given the latter's juxtaposition with Greenland, with the North American reference pole, Model II produces a better fit for the 272 and $244 \mathrm{Ma}$ poles than Model I (Fig. 7C). Due to the spread in Permian-Early Triassic poles mean GCD is high for all fits $\left(15-16^{\circ}\right)$. 


\subsection{Ellesmere}

As for Greenland and Svalbard, there are too few poles from Ellesmere to construct a separate and robust APW path. The Permian pole is anomalous (ca. $25^{\circ}$ offset from those of North America) but Cretaceous poles are in better agreement with the reference path (Fig. 7D). The GCD for all poles (Fig. 7D) compared with the combined North America-Europe RM path is large $\left(14 \pm 8^{\circ}\right)$. Rowley and Lottes [34] 'detached' Ellesmere from North America in order to account for extension in the Arctic Oceans. We tested their Ellesmere vs. North America Euler rotation parameters, but this results in a significant increase in $\operatorname{GCD}\left(20 \pm 11^{\circ}\right)$; for want of any better model, we keep Ellesmere in its present-day relative position with respect to North America in Fig. 6.

\section{Paleogeography and pre-drift extension}

Selected paleogeographic reconstructions for the North Atlantic region are shown in Fig. 6. They are based on the North America-Europe RM master path listed in table 2 in the EPSL Online Background Dataset ${ }^{1}$ and the reconstruction parameters of table 3 in the EPSL Online Background Dataset ${ }^{1}$. In the Early-Mid-Triassic (ca. $240 \mathrm{Ma}$ ), Eurasia and North America (as part of Pangea) stretched from the equator to ca. $45^{\circ} \mathrm{N}$, with the 30 th parallel running through Central Greenland and Central Norway (Fig. $6 a, b)$. During the later Triassic and the Jurassic, the North Atlantic bordering continents gradually moved northward (Fig. 5) [35], and in the MidJurassic, the 30th parallel ran roughly through northern Newfoundland and France according to the combined North America-Europe APW path. Recall, however, that during this part of the Jurassic, the separate APW paths for the two continents show the greatest discrepancies (Fig. 3B).

As Fig. 6a,b illustrates, the two models (I and II) differ in their reconstructions for Greenland, but are the same for Europe and North America. Model I uses a Bullard et al. [9] fit for Europe and Greenland that results in a tight fit in the Rockall area and a loose fit in the Arctic (Fig. 6a). Evidence for stretching of plates is recognized when the present-day contours of regions (that have separated from each other) overlap in paleo-reconstructions. The amount of overlap indicates how much extension may have occurred; for the Greenland-Europe domain we have visualized this by plotting the younger European continent-ocean boundary (COB) on the maps (Fig. 6). In Model I the largest overlap (450-500 km) is recognized in the Rockall area during the Triassic (Fig. 6a), but more than $50 \%$ of this overlap is eliminated by Mid-Jurassic times (Fig. 6c). Conversely, in Model I Mid-Norway and North Norway show a large compressional component in the same interval. This is difficult to reconcile with the geological history of these areas, and that is why the Bullard et al. [9] reconstruction has been spurned by many workers (e.g. [4]). Model I extension and compression in the NE Atlantic are portrayed in Fig. 8A, based on a calculation of the net-fit difference between Europe-North America and Greenland-North America. We notice that Rockall remained in extension throughout the entire interval, with rates of ca. $1 \mathrm{~cm} / \mathrm{yr}$ during Late Triassic-Middle Jurassic times (Fig. 8). Mid- and North Norway have a principal component of compression (ca. $300 \mathrm{~km}$ ) in the Late Triassic-Early Jurassic in Model I, followed by extension after about $180 \mathrm{Ma}$. The Tertiary velocity curves (Fig. 8A) are broadly similar to sea-floor spreading rates in the NE Atlantic estimated from magnetic anomaly/fracture flow lines in Fig. 8B [36]. Sea-floor spreading rates, however, are estimated as half-spreading rates whereas our velocity curves (Fig. 8A) are 'full-spreading values' based on best fit magnetic anomalies. Sea-floor spreading rates attained a maximum during NE Atlantic opening ( $\sim 50 \mathrm{Ma})$, subsequently decreased to a minimum during the Oligocene, followed by a recovery during the Miocene (Fig. 8B). Pre-drift extension or compression rates were always less than sea-floor spreading rates.

The later Mesozoic transition from an initial, Triassic, Bullard et al. [9] reconstruction is problematic not only for the evolution of the Arctic [34] but also for the evolution of the Mid-Norwe- 


\begin{tabular}{|c|c|c|c|c|c|c|c|c|c|c|c|}
\hline \multirow[t]{2}{*}{ A) } & Mio & Oli & Eoc & Pal & Late & Early & Late & Middle & Early & Late & \\
\hline & \multicolumn{4}{|c|}{ Tertiary } & \multicolumn{2}{|c|}{ Cretaceous } & \multicolumn{3}{|c|}{ Jurassic } & & iassic \\
\hline
\end{tabular}
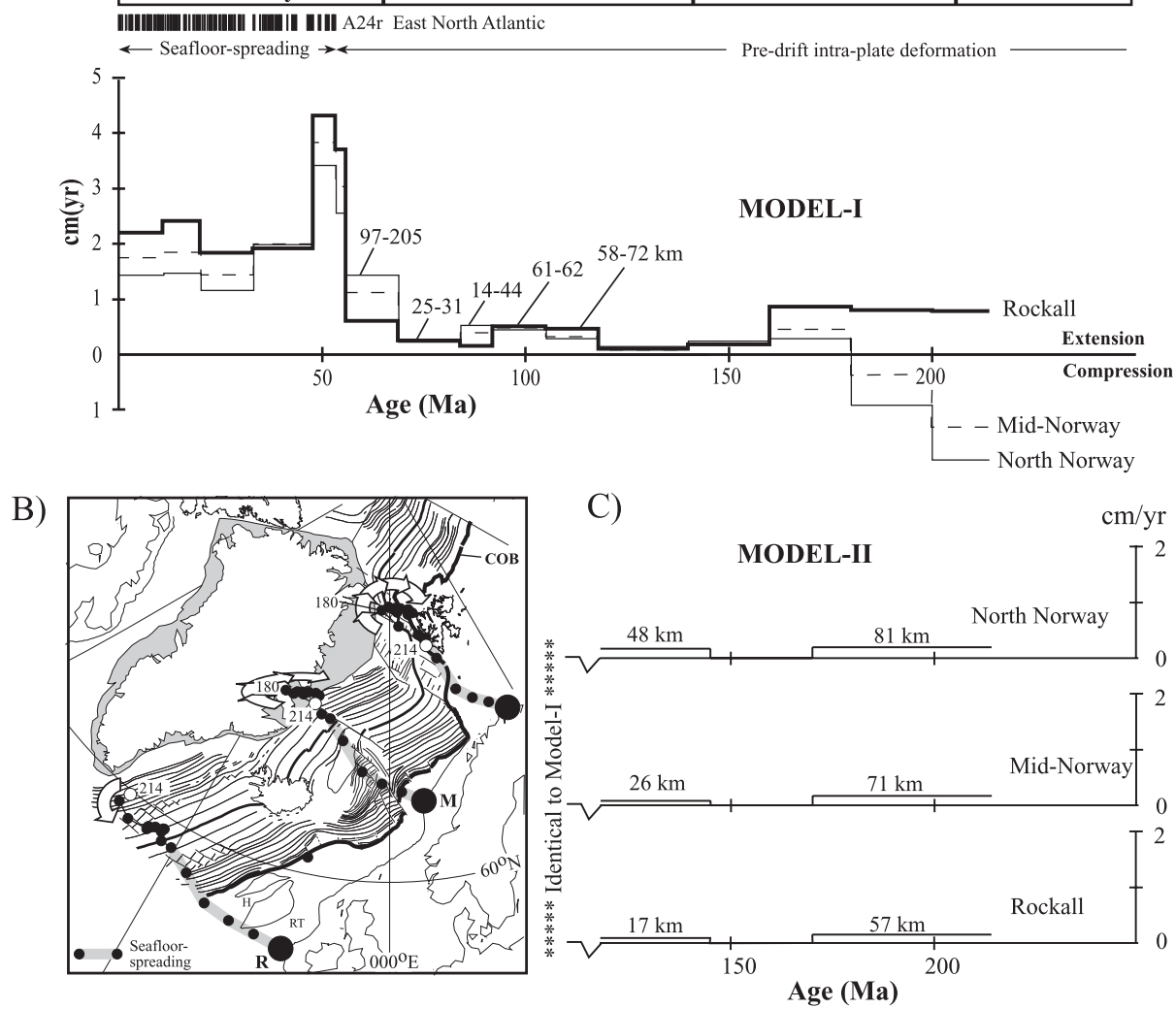

Fig. 8. (A) Calculated extension/compression or 'sea-floor spreading rates' ('synthetic full-spreading rates' based on Europe vs. Greenland). Magnetic polarity scale after Cande and Kent [3]. Calculations are done for three specific locations along the Eurasian plate, Rockall (R, $\left.54^{\circ} \mathrm{N}-347^{\circ} \mathrm{E}\right)$, Mid-Norway $\left(\mathrm{M}, 66^{\circ} \mathrm{N}-6^{\circ} \mathrm{E}\right)$ and North Norway $\left(\mathrm{N}, 71^{\circ} \mathrm{N}-27^{\circ} \mathrm{E}\right)$; for location see (B)). (B) Locations used for calculations in (A) are marked as large solid circles. Smaller solid circles show the pathway of these locations when reconstructed (keeping Greenland fixed) - open circle is the location at $214 \mathrm{Ma}$ [9]. Magnetic anomalies (A24 and younger) and fractures in the NE Atlantic in digital form from [39]. (C) Estimates of pre-drift extension between Europe and Greenland/ Svalbard in Model II (Fig. 6b) for Rockall, Mid-Norway and North Norway (as in (B)). Numbers denote the amount of extension in kilometers over the time interval considered, and Model I and II estimates are similar from Mid-Jurassic onwards. Main extensional events are in the Cretaceous (peak in latest Cretaceous) with an early phase of Late Triassic-Early Jurassic extension. Early Cretaceous-Early Tertiary cumulative extension (pre-A24) amounts to $312 \mathrm{~km}$ (Rockall), $398 \mathrm{~km}$ (Mid-Norway) and 455 $\mathrm{km}$ (North Norway).

gian Shelf. In Model II we overcome these problems by changing the Greenland-North America and Greenland-Europe fits for the Early Mesozoic (Fig. 6b). Both Models I and II are imagined to evolve into the same Mid-Jurassic fit of Fig. 6c. In Model II, a tight Norwegian-Greenland fit is proposed for the Early Mesozoic (and the Late Paleozoic), followed by Mid-Norwegian Shelf extension after $214 \mathrm{Ma}$ (Fig. 8C). In this model, the bulk of pre-drift extension occurs in the Early
Cretaceous to Early Tertiary. Assuming that no deformation has taken place within the Eurasian plate since the Early Triassic, the Model II reconstruction implies a large compression within the Arctic Ocean northwest of Svalbard at later times (cf. Fig. 6b,c).

The Early Tertiary (ca. $54 \mathrm{Ma}$ ) reconstruction places most of North America and Eurasia north of $30^{\circ} \mathrm{N}$ (Fig. 6) and is similar to that of Torsvik et al. [18]. 


\section{Conclusions}

A Bullard et al. fit [9] for Europe and North America is shown to be superior from Late Carboniferous to Late Triassic times, by comparing APW paths in various reconstructions. However, the continental configuration in northern Pangea must have changed systematically between about 214 and $170 \mathrm{Ma}$. We interpolate between the Bullard et al. [9] fit and a suggested Jurassic fit at about $170 \mathrm{Ma}$ [22], because the paleomagnetic data indicate a looser configuration in an eastwest sense for Europe and North America in Early Jurassic time. Post-Jurassic reconstructions are adopted from Srivastava and Roest [2] and Roest et al. (personal communication).

Our fits minimize differences in the Late Carboniferous-Early Jurassic and Late CretaceousTertiary segments of the APW paths, but an enigmatic difference exists in the paths for most of the Jurassic, whereas for the Early Cretaceous the data from Europe are nearly non-existent.

Greenland's position is problematic in a Bullard et al. [9] fit, because of a Late Triassic-Early Jurassic regime of compression that would be inherently required for Central and Northern Norway, but which is geologically not defensible. We suggest a radically new fit for Greenland in between Europe and North America in the Early Mesozoic.

\section{Acknowledgements}

We thank E.A. Eide, M.W. McElhinny, V. Courtillot and G. Muttoni for valuable comments. This study resulted from a project initiated at the 1999 4th Nordic Paleomagnetic Workshop, organized by Prof. Niels Abrahamsen in Aarhus. We thank Niels and the Department of Earth Sciences in Aarhus for their organization and hospitality and acknowledge all the participants for their stimulating interest in this work; the Danish Natural Science Research Council and the Norwegian Research Council are thanked for their financial support of the workshop. The contribution of R.V.d.V. was supported by the National Science Foundation (NSF), Division of Earth Sci- ences, Grant EAR 9705755. J.G.M. was supported by NSF Grant EAR 9805306 and by the US-Norway Fulbright Foundation. T.H.T. and J.M. were supported by VISTA (Norwegian Academy of Sciences-Statoil) and the BAT project.[SK]

\section{References}

[1] W.R. Roest, S.P. Srivastava, Seafloor spreading in the Labrador Sea: a new reconstruction, Geology 17 (1989) $1000-1004$.

[2] S.P. Srivastava, W.R. Roest, Seafloor spreading history II-IV, in: J.S. Bell (Ed.), East Coast Basin Atlas Series: Labrador Sea, Atlantic Geoscience Centre, Geol. Surv. Can. Map sheets L17-2-L17-6, 1989.

[3] S.C. Cande, D.V. Kent, Revised calibration of the geomagnetic polarity timescale for the Late Cretaceous and Cenozoic, J. Geophys. Res. B 100 (1995) 6093-6095.

[4] A.L. Lottes, D.B. Rowley, Reconstruction of the Laurasian and Gondwana segments of Permian Pangaea, in: W.S. McKerrow, C.R. Scotese (Eds.), Palaeozoic Palaeogeography and Biogeography, Geol. Soc. Lond. Mem. 12, 1990 , pp. $383-395$.

[5] L.S. Frei, A.V. Cox, Relative displacements between Eurasia and North America prior to the formation of oceanic crust in the North Atlantic, Tectonophysics 142 (1987) $111-127$.

[6] R. Van der Voo, Phanerozoic paleomagnetic poles from Europe and North America and comparisons with continental reconstructions, Rev. Geophys. 28 (1990) $167-$ 206.

[7] R. Van der Voo, Paleomagnetism of the Atlantic, Tethys and Iapetus Oceans, Cambridge University Press, 1993, $411 \mathrm{pp}$.

[8] J.-E. Cole, J. Peachey, Evidence for pre-Cretaceous rifting in the Rockall Trough: an analysis using quantitative plate tectonic modeling, in: A.J. Fleet, S.A. Boldy (Eds.), Petroleum Geology of Northwest Europe: Proceedings of the 5th Conference, Petroleum Geology '85 Ltd., Geol. Soc. Lond., 1999, pp. 359-370.

[9] E.C. Bullard, J.E. Everett, A.G. Smith, The fit of the continents around the Atlantic, R. Soc. Lond. Philos. Trans. Ser. A 258 (1965) 41-51.

[10] T.H. Torsvik, M.A. Smethurst, R. Van der Voo, A. Trench, N. Abrahamsen, E. Halvorsen, Baltica - A synopsis of Vendian-Permian palaeomagnetic data and their palaeotectonic implications, Earth Sci. Rev. 33 (1992) $133-152$.

[11] T.H. Torsvik, M.A. Smethurst, J.G. Meert, R. Van der Voo, W.S. McKerrow, M.D. Brasier, B.A. Sturt, H.J. Walderhaug, Continental break-up and collision in the Neoproterozoic and Palaeozoic: A tale of Baltica and Laurentia, Earth Sci. Rev. 40 (1996) 229-258. 
[12] S.P. Srivastava, J. Verhoef, Evolution of Mesozoic sedimentary basins around the North Central Atlantic: a preliminary plate kinematic solution, in: J. Parnell (Ed.), Basins on the Atlantic Seaboard: Petroleum Geology, Sedimentology and Basin Evolution, Geol. Soc. Spec. Publ. 62, 1992, pp. 397-420.

[13] F.M. Gradstein, F.P. Agterberg, J.G. Ogg, J. Hardenbol, P. Van Veen, J. Thierry, Z. Huang, A Triassic, Jurassic and Cretaceous time scale, in: W.A. Berggren, D.V. Kent, M.P. Aubry, J. Hardenbol (Eds.), Geochronology, Time Scales and Global Stratigraphic Correlation, Spec. Publ. Soc. Sed. Geol. 54 (1995) 95-126.

[14] W.A. Berggren, D.V. Kent, M.P. Aubry, J. Hardenbol, Geochronology, time scales and global stratigraphic correlation: unified temporal framework for an historical geology, in: W.A. Berggren, D.V. Kent, M.P. Aubry, J. Hardenbol (Eds.), Geochronology, Time Scales and Global Stratigraphic Correlation, Spec. Publ. Soc. Sed. Geol. 54 (1995) 130-212.

[15] P. Bryan, R.G. Gordon, Rotation of the Colorado Plateau: an updated analysis of paleomagnetic data, Geophys. Res. Lett. 17 (1990) 1501-1504.

[16] R.S. Molina Garza, G.D. Acton, J.W. Geissman, Carboniferous through Jurassic palaeomagnetic data and their bearing on rotation of the Colorado plateau, J. Geophys. Res. 103 (1998) 24179-24188.

[17] L.M. Larsen, D.C. Rex, W.S. Watt, P.G. Guise, ${ }^{40} \mathrm{Ar} /{ }^{39} \mathrm{Ar}$ dating of alkali basaltic dykes along the south-west coast of Greenland: Cretaceous and Tertiary igneous activity along the eastern margin of the Labrador Sea, Geol. Greenl. Surv. Bull. 184 (1999) 19-29.

[18] T.H. Torsvik, J. Mosar, E.A. Eide, Cretaceous-Tertiary geodynamics: A North Atlantic exercise, Geophys. J. Int. (2001), in press.

[19] P.J. Wynne, E. Irving, K. Osadetz, Paleomagnetism of the Esayoo Formation (Permian) of northern Ellesmere Island: Possible clues to the solution of the Nares Strait dilemma, Tectonophysics 100 (1983) 241-256.

[20] P.E. Jupp, J.T. Kent, Fitting smooth paths to spherical data, Appl. Stat. 36 (1987) 34-36.

[21] R. Van der Voo, T.H. Torsvik, Evidence for Permian and Mesozoic non-dipole fields provides an explanation for the Pangea reconstruction problems, Earth Planet. Sci. Lett. (2001), this issue.

[22] J.-Y. Royer, R.D. Müller, L.M. Gahagan, L.A. Lawver, C.L. Mayes, D. Nürnberg, J.G. Sclater, A global isochron chart: Univ. Texas Inst. for Geoph. Tech. Rep. No. 117, 1992.

[23] R.D. Müller, J.Y. Royer, L.A. Lawver, Revised plate motions relative to the hotspots from combined Atlantic and Indian Ocean hotspot tracks, Geology 21 (1993) 275278.

[24] V. Courtillot, J. Besse, H. Théveniaut, North American Jurassic apparent polar wander: the answer from other continents?, Phys. Earth Planet. Int. 82 (1994) 87-104.
[25] J. Mosar, Depth of extensional faulting on the Mid-Norway Atlantic passive margin, Nor. Geol. Surv. Bull. 437 (2001), in press.

[26] D.V. Kent, L.B. Clemmensen, Paleomagnetism and cycle stratigraphy of the Triassic Fleming Fjord and Gipsdalen Formations of East Greenland, Bull. Geol. Soc. Den. 42 (1996) 121-136.

[27] E. Hartz, T.H. Torsvik, A. Andresen, Carboniferous age for the East Greenland 'Devonian' Basin: Palaeomagnetic and isotopic constraints on age, stratigraphy and plate reconstructions, Geology 25 (1997) 675-678.

[28] W.S. McKerrow, J.F. Dewey, C.R. Scotese, The Ordovician and Silurian development of the Iapetus Ocean, Spec. Pap. Paleont. 44 (1991) 165-178.

[29] T.H. Torsvik, R. Løvlie, B.A. Sturt, Palaeomagnetic argument for a stationary Spitsbergen relative to the British Isles (Western Europe) since late Devonian and its bearing on North Atlantic reconstruction, Earth Planet. Sci. Lett. 75 (1985) 278-288.

[30] D.R. Watts, Palaeomagnetism of the Lower Carboniferous Billefjorden Group, Spitsbergen, Geol. Mag. 122 (1985) 383-388.

[31] M. Jelenska, Aspects of pre-Tertiary paleomagnetism of Spitsbergen and their tectonic implications, Tectonophysics 139 (1987) 99-106.

[32] J. Nawrocki, Paleomagnetism of Permian through Early Triassic sequences in central Spitsbergen: implications for paleogeography, Earth Planet. Sci. Lett. 169 (1999) 59-70.

[33] J.I. Falleide, E. Vågnes, S.T. Gudlaugsson, Late Mesozoic-Cenozoic evolution of the southwestern Barents Sea in a rift-shear tectonic setting, Mar. Petrol. Geol. 10 (1993) 186-214.

[34] D.B. Rowley, A.L. Lottes, Plate-kinematic reconstructions of the North Atlantic and Arctic: Late Jurassic to Present, Tectonophysics 155 (1988) 73-120.

[35] D.V. Kent, P.E. Olsen, Magnetic polarity stratigraphy and paleolatitude of the Triassic-Jurassic Blomidon Formation in the Fundy basin (Canada): implications for early Mesozoic tropical climate gradients, Earth Planet. Sci. Lett. 179 (2000) 311-324.

[36] T.H. Torsvik, J. Mosar, Seafloor spreading rates in the North Atlantic-Report for Chevron, Geological Survey of Norway, Int. Rep., 1999, 9 pp.

[37] A.F. Embry, Mesozoic history of the Arctic Islands, in: H.P. Trettin (Ed.), The Geology of North America, Geology of the Innuitian Orogen and Arctic Platform of Canada and Greenland, Volume E, Geological Society of America, 1991, pp. 369-434.

[38] F. Surlyk, Tectonostratigraphy of North Greenland, Grønl. Geol. Unders. Bull. 160 (1991) 25-47.

[39] J. Skogseid, S. Planke, J.I. Faleide, T. Pedersen, O. Eldhom, F. Neverdal, NE Atlantic continental rifting and volcanic margin formation, in: A. Nøttvedt (Ed.), Dynamics of the Norwegian Margin, Geol. Soc. London, Spec. Public. 167 (2000) 295-326. 